\title{
New Data about the Paleo Environment of the Papo-Seco Formation (Lower Cretaceous) of Southern Portugal
}

\author{
Silvério Figueiredo ${ }^{1,2,3}$, Ioanna Bachtsevanidou Strantzali ${ }^{2}$, Pierluigi Rosina ${ }^{1,3}$ and Marta Gomes ${ }^{2,4}$ \\ 1. Departmental Unit of Archaeology, Conservation and Restore and Heritage, Polytechnic Institute of Tomar, Tomar 2300-313, \\ Portugal \\ 2. Department of Palaeontology, Centro Português de Geo-História e Pré-História, São Caetano-Golegã 2150-265, Portugal \\ 3. Geosciences Center, University of Coimbra, Coimbra 3030-790, Portugal \\ 4. Department of Geosciences, University of Évora, Évora 7000, Portugal
}

\begin{abstract}
New vertebrate and invertebrate remains are reported from the basal deposits (marls, sands and gravels) of Papo-Seco Formation (Lower Barremian, Lower Cretaceous) of Areias do Mastro, nearby Cabo Espichel, Sesimbra, south of Lisbon. The studied layers were formed in an environment of shallow-marine features (lagoon, estuary). Recent paleontological inspection generated several vertebrate and invertebrate remains, including shells and trace fossils (casts and molds) of gastropods and bivalves; after examination, there were identified bones and teeth of fish, crocodiles, dinosaurs, pterosaurs and turtle shell fragments. The new data constitute an important contribution to the knowledge of vertebrate paleo-diversity for the environment during the Lower Cretaceous of Portugal.
\end{abstract}

Key words: Paleo-environment, Iguanodonts, Baryonyx, Lepidotes, Cabo Espichel, Lower Cretaceous.

\section{Introduction}

First palaeontological investigations in Cabo Espichel took place in the 19th century $[1,2]$. The Portuguese geological survey reported dinosaur and crocodile teeth from the Papo-Seco Formation; at Boca do Chapim quarry [3]. Later, Lapparent and Zbyszewski [4] reported turtle remains, crocodile teeth and bones as well as dinosaurian remains. Among the latter, there were initially referred two teeth fragments assigned to megalosauridae [4], later classified as carnosauria incertae sedis [5]. Additionally, herbivorous dinosaur remains were further reported such as teeth, caudal vertebrae and the distal end of a right femur identified as Iguanodon together with teeth of Astrodon (= Pleurocoelus) valdensis [4-6]. According to Antunes and Mateus [7], these sauropod teeth are insufficient to assign a more specified classification. In Museu Geológico of the Laboratório Nacional de Energia e

Corresponding author: Silvério Figueiredo, professor, Ph.D., main research field: palaeontology.
Geologia (LNEG), in Lisbon, there is a dinossaur tooth from Boca do Chapim quarry (MGIGM.10), displayed at the Museum's inventory as an Iguanodon, which was identified and assigned to cf. Pelorosaurus [8]. Both of these sauropod designations, Pelorosaurus or Astrodon are in accordance with descriptions of material from various locations in the European Early Cretaceous such as the English Wealden, in spite of affinities between these taxa being uncertain [9]. Fragments of jaws found at Boca do Chapim by Sauvage [3] were identified under the name of the crocodile Suchosaurus girardi; they were later re-examined by Buffetaut and classified as the spinosaurid Baryonyx, based on similarities with the holotype of Baryonyx walkeri from the English Barremian [10].

In the area of Cabo Espichel, dinosaur tracks are also known: Praia do Cavalo has theropod footprints; Pedra da Mua has trackways of sauropods and theropods (both quarries from the late Jurassic) and Lagosteiros (Lower Cretaceous) with trackways of theropods and ornithopods $[1,2,7,11-15]$. 
New discoveries have been made in Papo-Seco Formation. Recently, Mateus published skull and postcranial bones attributed to Baryonyx walkeri in the location under the dubious name of Praia das Aguncheiras [16], being the established location of Praia do Guincho. In scope of the palaeontological investigations carried out by Centro Português de Geo-História e Pré-História (CPGP) new data are reported. In Boca do Chapim, a preliminary analysis of the discovered material showed several bones of an ornithopod dinosaur $[17,18]$. In Areia do Mastro, there have already been reported vertebrate bone fragments and teeth such as fish (cf. Lepidotus $s p$.), crocodiles ( $c f$. Anteophtalmosuchus sp.), pterosaurs (Ornithocheiridae indet. and Ctenochasmatoidea indet.) and dinosaurs (Baryonyx sp, Iguanodontoidea inde., Iguanodontsb and Sauropoda indet.) [19].

During the following investigations, carried out by CPGP, there was collected a set of fossil vertebrates and invertebrates that enables conclusions regarding the paleo-environments in the Barremian of Papo-Seco Formation. This study is based on a work already published [19] in which it is described the paleo-environmental context of a number of vertebrate remains. Herein authors present several new findings and authors analyze preliminary thoughts over the paleo-environmental framework.

\section{Materials}

This study is based on a collection of 48 vertebrate and invertebrate fossils from Areias do Mastro (Fig.1), curated in the palaeontological collection of Centro Português de Geo-História e Pré-História (CPGP). These materials resulted after survey at the cliffs of Areias do Mastro (1998-2016) and excavation of seven clay layers in the lower part of the cliffs (2004-2009; 2016).

\section{Results and Discussion}

\subsection{Geologic Setting}

The fossiliferous stratigraphic level examined herein belongs to the Papo-Seco Formation (Lower Barremian [20]. It is located near Sesimbra, in the SW of the Setúbal Peninsula, at about $40 \mathrm{~km}$ south of Lisbon (Portugal) (Fig. 2). The site, with coordinates $38^{\circ} 24^{\prime} 50.8^{\prime \prime} \mathrm{N} 9^{\circ} 13^{\prime} 20.8^{\prime \prime} \mathrm{W}$, is located in a small beach (Areias do Mastro, about $1.5 \mathrm{~km}$ north of Cabo Espichel) at the coastal cliffs of the Cabo Espichel anticline. This formation lies between the Areias do Mastro Formation and the Boca do Chapim Formation [20].

The Papo-Seco Formation is about $18.5 \mathrm{~m}$ thick and mainly consists of marls and silty clays that alternate with sandstones [20]. A sedimentological study of the fossiliferous site in the lowest exposures of the Papo-Seco Formation (Lower Barremian) reveals the occurrence of two main continental facies and one transitional interbedded, all in horizontal association without any visible unconformities (Figs. 3 and 4).

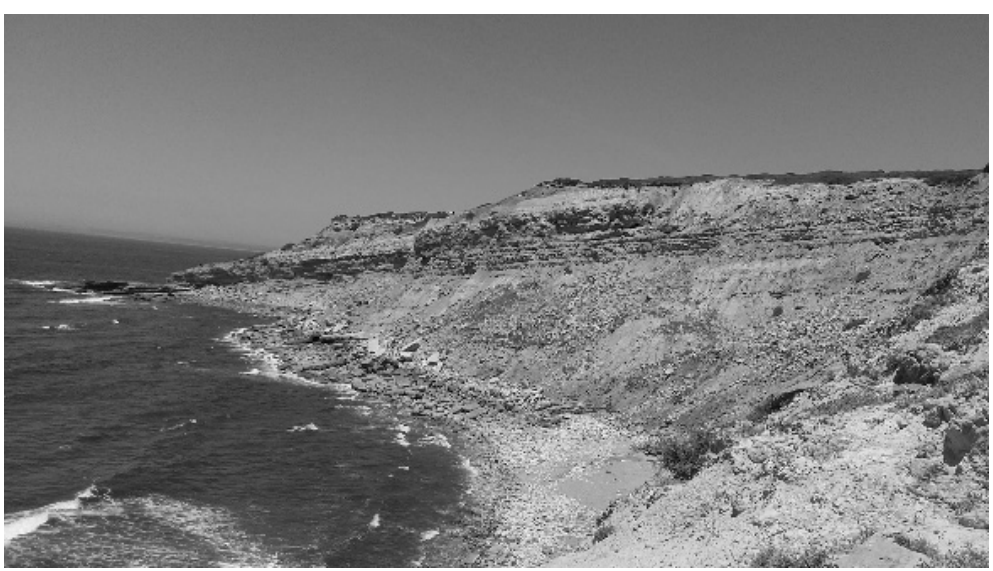

Fig. 1 The Areias do Mastro quarry. 


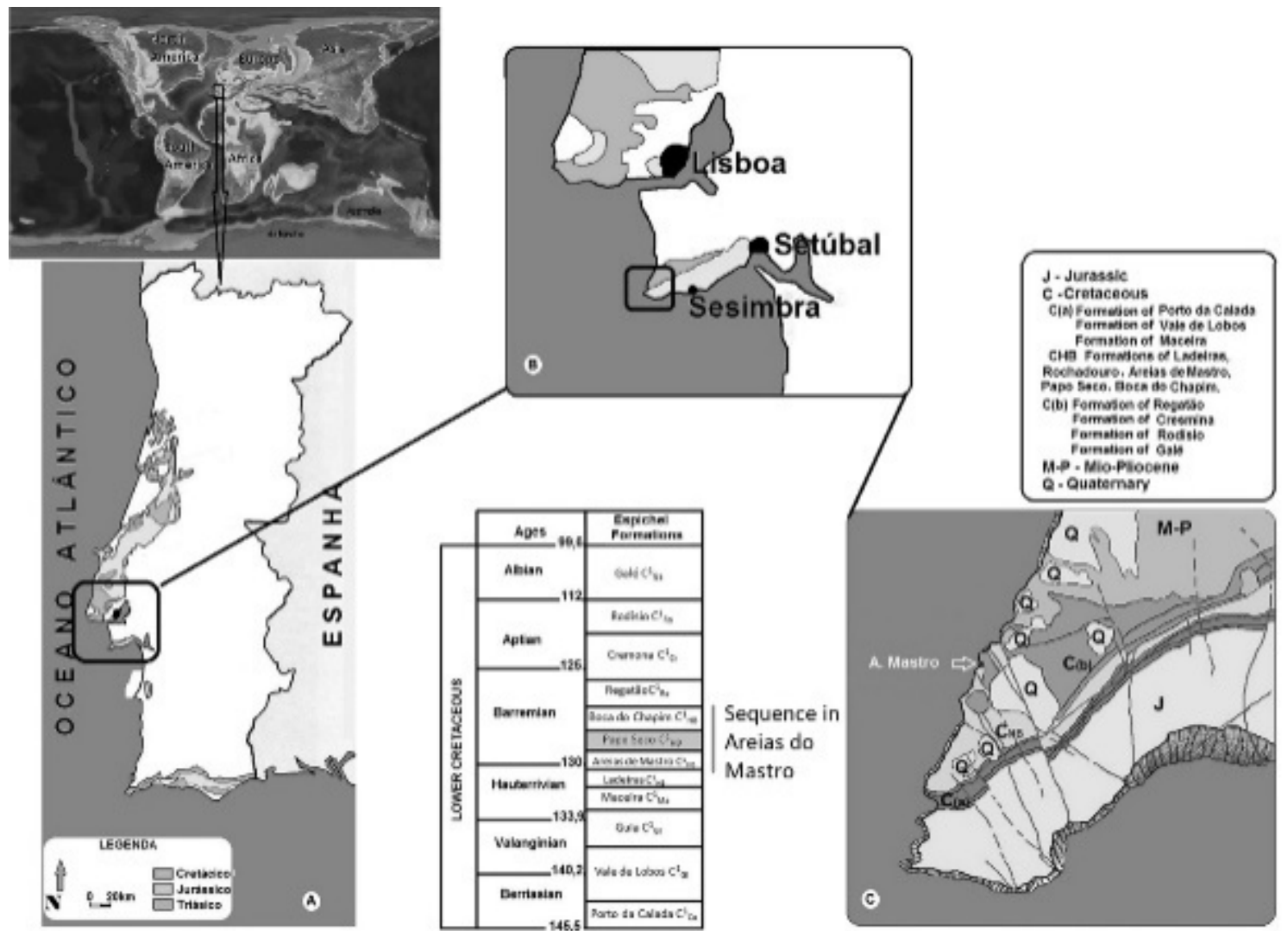

Fig. 2 The locality Areias do Mastro, geological context, chronological column and units showing the Mesozoic of Portugal (A) the Mesozoic of Lisbon and Setúbal Peninsulas; (B) geology and geological formations of the Cabo Espichel and Areias do Mastro sequences; (C) The dating of the Cretaceous ages is according to the International Chronostratigraphic Chart (2015). Source: [19].

Macroscopic field (sector 1) description and classification of the fossiliferous bioclastic marl unit (around $2 \mathrm{~m}$ thick):

C1.a (lower unit): mudstone consisting of soft and usually wet blackish clay. It is a horizontal layered and homogeneous deposit, with grain size $<0.001 \mathrm{~cm}$, and very thick bedded ( $>50 \mathrm{~cm}$ thickness).

C1.b (intermediate unit): a transitional layer of sandy clay thick to thin bedded ( $\sim 70 \mathrm{~cm}-30 \mathrm{~cm}$ thick) with undistinguishable limits. At the bottom appears as dark gray clay. It gradually becomes upwards light gray, slightly more sandy (10\% grains) and better drained.

C2 (top unit): sandstone that appears grayish to brown (ferruginous), carbonate-rich thick bedded $(\sim 30$ $\mathrm{cm}$ ) it is a quartz-rich arenite deposit (grain size $\sim 2$ millimeter in diameter). It consists of a dominant sand fraction (80\%; mainly quartz and clay minerals) with a clayey matrix.

Biogenic components:

Various sizes of sea snails, marine gastropod mollusks, brachiopods and bivalves shell fragments, but also fossilized wood fragments. Fossilized fish teeth and bones, vertebrate fragments of turtles and dinosaurs were unearthed.

Sedimentary analysis of sector 2 also with $\sim 2 \mathrm{~m}$ thickness reveals the following sedimentary sequence [19]:

C1 (lower unit): argillaceous clay unit $(\sim 30 \mathrm{~cm}$ thickness) with residual carbonates and a very poor presence of sand.

C2: Sandy clay ( $\sim 60 \mathrm{~cm}$ thickness $)$ with more carbonates than the $\mathrm{C} 1$.

C3: Sandy loam ( $\sim 20 \mathrm{~cm}$ thick). This layer is slightly marly with more carbonates than the $\mathrm{C} 1$ and $\mathrm{C} 2$, and it is the layer with the most sand. 


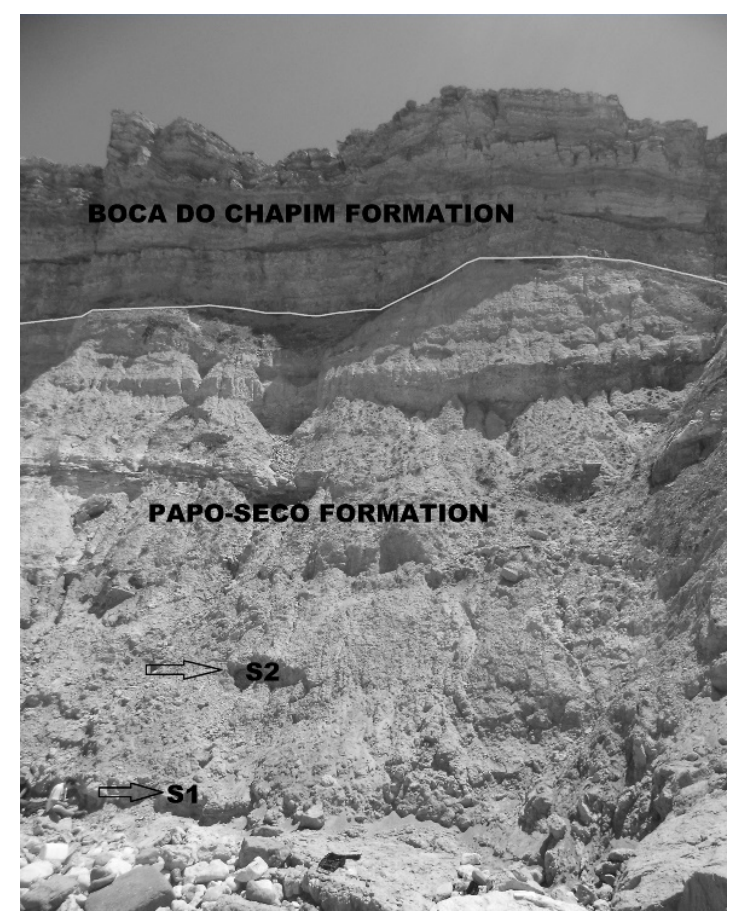

Fig. 3 The Papo-Seco Formation and the exact locality of the two layers "sectors" studied.

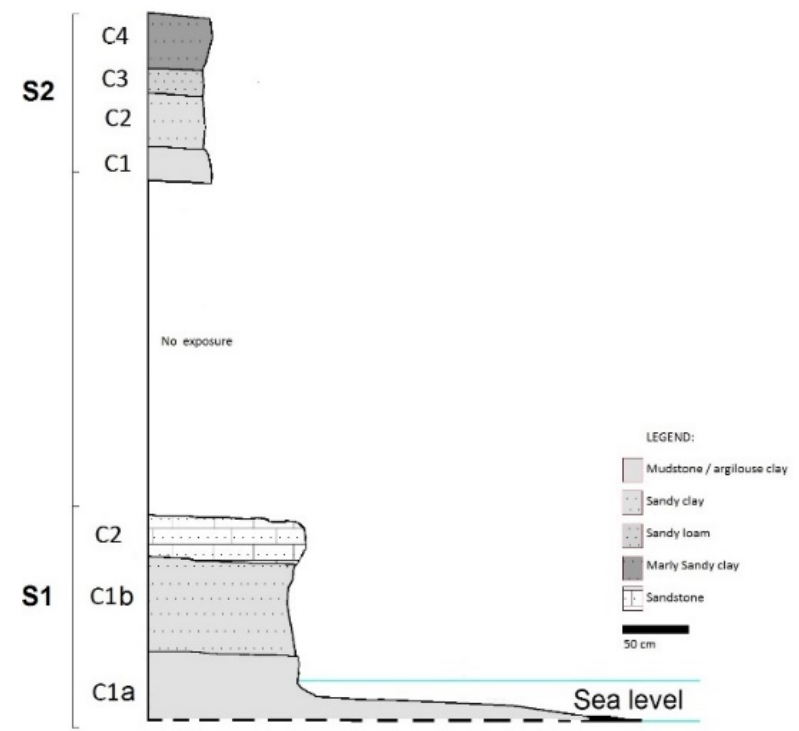

Fig. 4 Stratigraphic column of the layers studied in the Areias do Mastro quarry.

C4 (top unit): Marly sandy clay ( $\sim 50 \mathrm{~cm}$ thick). This layer is the most carbonated layer and presents sparse bioturbation.

Biogenic components

During the field work invertebrate remains were collected (mostly bivalves of the genus Nipponomaia).
Vertebrate fossils were also collected and some of them have been published: Fish teeth (Lepidotes); crocodiles teeth ( $c f$. Anteophthalmosuchus sp.); pterosaurs teeth (Ornitocheiridae and Ctenochasmatoidea) and teeth and bones of dinosaurs (Baryonyx, ornithopods and sauropods) [19].

\subsection{Paleoecology}

The sedimentological analysis and the taxonomical identification demonstrate in both sectors an evolution from a more closed to open sea environments. Macroscopic description of the samples of the sediments of the "sector 1 " indicate that the "layer C1" was deposited in a lagoon environment and the "layer $\mathrm{C} 2$ " in a coastal one. The "layer C1b" is a transitional environment between lagoon and coastal. The sedimentological analysis of the layers in "sector 2" shows a similar scenario. It demonstrates an evolution from a lagoon-like (cat's-eye pond) environment to a coastal environment, as documented by the marly clays that alternate with limestone layers. Between these two depositional phases, the increase in the sandy fraction indicates the opening of the lagoon and, possibly, an estuarine episode (with over $65 \%$ of sand). A progressive increase in carbonate relates with an increasing influence of marine processes; the concentration of organic matter could be related either to interplay of aerobic/anaerobic conditions during deposition or to post-depositional processes.

\subsubsection{Fossil Compositional Diversity}

Invertebrate fossils (Figs. 5 and 6): Eomiodon Cuneauos: Indicative of brackish environment of estuarine type. Nipponomaia: Fresh water molluscs of lacustrine floodplain environment). Natica $s p$.: Naticids live on sandy substrates, at a great variety of depths depending on the species (from the intertidal zone to thousands of meters in depth). Chemnitzia: Coastal, estuary, shallow subtidal, marine environments. Turritella sp.: abundant on muddy sediment in shallow waters. Ostreida: Inhabiting coral debris in beach sandstones. 

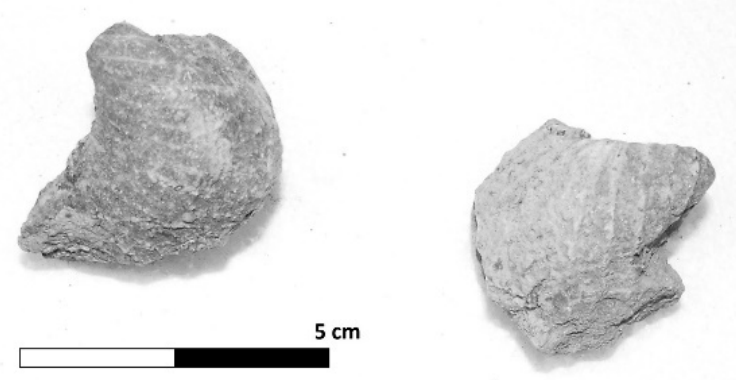

Fig. 5 Bivalves of Sector 2: Nipponomaia sp..

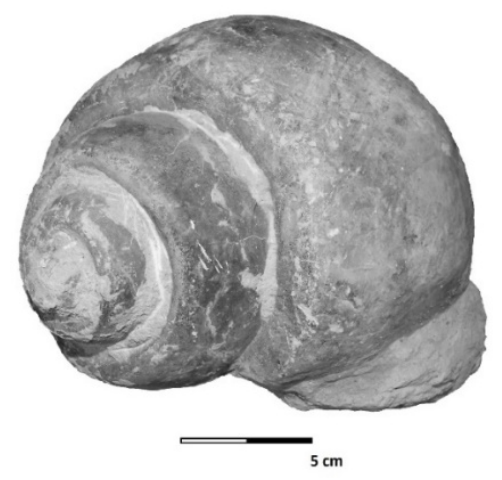

Fig. 6 Naticidae from layer C1a of the sector 1.

Fish: Lepidotes (Figs. 9 and 10): Inhabiting fresh water lakes and shallow seas, shared habitat with the rest encountered remains of crocodiles, turtles. Pycnodontids: shallow-water seas and sharks as Hybodus: shallow seas.

Tetrapods: Turtles (Figs. 7 and 8): semi-aquatic to marine; crocodiles (Fig. 10): semi-aquatic; pterosaurs (Fig. 10): littoral zone and dinosaurs (Fig. 10): terrestrial and littoral zones.

The crocodile Anteophthalmosuchus sp. (Fig. 10) was a Semi-aquatic crocodile. It lived in freshwater wetlands, such as marshes, swamps, streams, rivers, ponds, and lakes swampy. Anteophthalmosuchus also lived in open water areas; Pterosaurs (Ornithocheiridae and Ctenochasmatoidea) (Fig. 10) as fish-eating animals, they lived near the sea and lagoons; Baryonix (Fig. 10) inhabited littoral zones, fluvial, estuarine, lagoon areas.

\subsubsection{Food Chain}

In the examined layers, authors verified the occurrence of a clear food chain pyramid constituted by the identified fossil species.

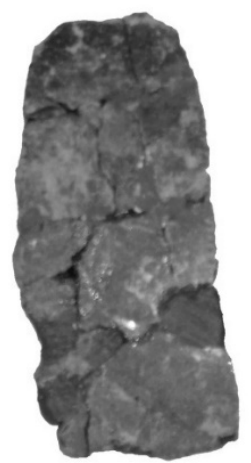

A

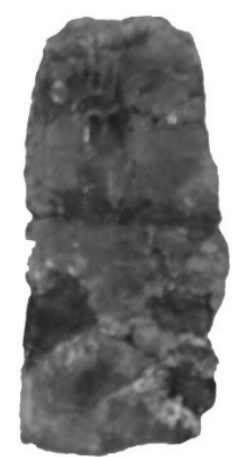

B
Fig. 7 Turtles remains in S1, layer C1b: Costal plate (A-dorsal view; B-ventral view).

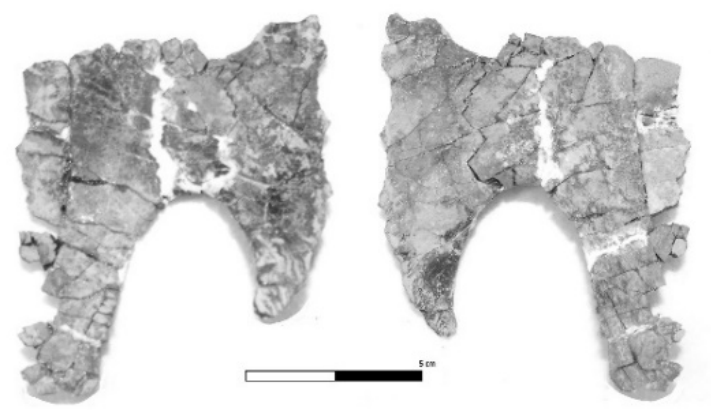

Fig. 8 Turtles remains in S1, layer C1b: Plastron (A-dorsal view; B-ventral view).

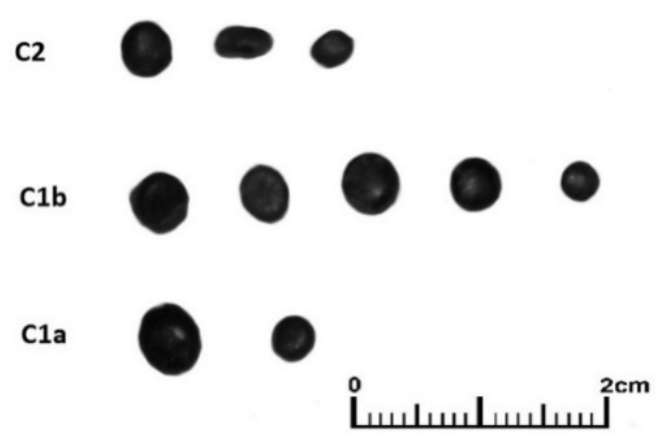

Fig. 9 Lepidotes teeth from sector 1.

In lower layers (Sector 1) was found an invertebrate community, made up of small bivalve and gastropods that would be preyed upon by larger gastropods (Naticidae) and by durophagous fishes (Lepidotes), in layer C1a. Authors found also turtle's fossils, in layer C1b. Turtle's diet varies greatly depending on the environment in which it inhabits. They eat aquatic plants, invertebrates such as insects, snails and worms; 


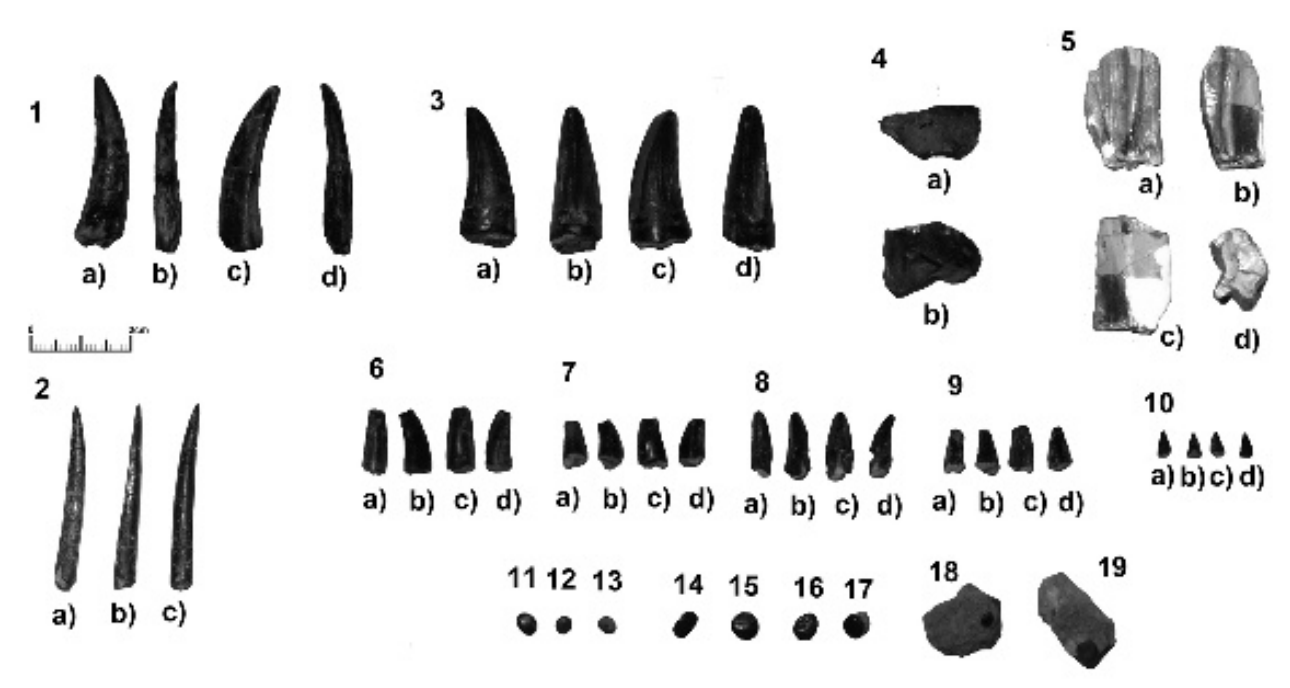

Fig. 10 Teeth present in the Sector 2:

1: Ornithocheiridae indet-CPGP.1.03.2 (a-labial surface; b-distal surface; c-lingual surface; d-medial surface); 2: Ctenochasmatoidea indet.-CPGP.1.09.1 (a-labial surface; b-distal surface; c-medial surface); 3: Baryonyx-CPGP.1.06.2. (a-labial surface; b-distal surface; c-lingual surface; d-medial); 4: Ornithopoda indet.-CPGP.1.03.3 (a-lingual surface; b-top view); 5: Iguanodont (cf. Mantellisaurus)-CPGP.1.01.2 (a-labial surface; b-distal surface; c-lingual surface; d-top view); 6-9: Anteophthalmosuchus sp.: 6-CPGP.1.03.1; 7-PGP.1.03.7; 8-CPGP.1.05.9; 9-CPGP.1.06.71; 10-CPGP.1.06.81 (a-labial surface; b-distal surface; c-lingual surface; d-medial surface);11-19 cf. Lepidotus sp. teeth (adapted and modified from Figueiredo et al. [19]).

and occasionally dead marine animals. Some freshwaters species are carnivorous, eating small fish and a wide range of aquatic fauna. Allegedly, in the lower layers the turtles were on the top of the food chain hierarchy.

In the upper layers (sector 2), the diversity of invertebrate fauna is poor, constituted only by Nipponomaia sp.. This bivalve would be preyed upon by the fish of the genus Lepidotes and likewise by Anteophthalmosuchus crocodile. In turn, the fish would be preyed upon by the Anteophthalmosuchus, Baryonyx and pterosaurs.

\subsection{Discussion}

The vertebrate fauna is composed primarily by crocodiles, turtles, pterosaurs and fish. The invertebrate animals are also abundant, with the mainly occurrences of gastropods and bivalves.

The majority of the fauna identified and the sedimentary analysis demonstrates the succession of a closed environment to a more open marine one. The presence of iguanodonts and sauropods, which are terrestrial animals, are foreign elements to the data in consonance with the sedimentary evolution and by the presence of the other taxa. Thus, they are considered as transported allochthonous material. Their presence can be explained either by their occasional roaming alongside lakes or estuarine zones (documented in the $\mathrm{C} 1, \mathrm{C} 2$ and $\mathrm{C} 3$ of the "sector 2", and where the remains of these dinosaurs occurred), for food or water or by post-mortem water transportation [21].

Regarding the blackish color of some fossils these possible were preserved as carbonized traces, since it is the common type of preservation. As for the color variations found among lighter to darker brownish tones, this is a consequence of different preservation in carbonaceous traces

The reddish beige and brown coloration is typical of the iron oxides-hydroxides, possibly limonite. The remaining specimens may be preserved as incarbonization, as a common type of preservation of organic molecules, showing characteristic dark black hue. However, to be sure of the chemical composition, further investigations are needed to be performed. 
Siliciclastic coarse grains, tend to preserve only large hard parts of the animals (i.e., bones, teeth and claws). Such sediments are generally related to high energetic deposition, and unidirectional flows, such as rivers and streams $[22,23]$.

The fauna of Papo-Seco formation may have been autochthonous; however, the terrestrial vertebrates thrived at different region not far away and on the same time, indicated by evidence in the other units. The Papo-Seco formation shows remarkable abundant preserved biota. Further investigations using Scanning Electron Microscopy equipped with Energy Dispersive X-ray Spectroscopy (SEM-EDS) would help identifying the presence of the mineralsand other possible elements, confirming their preservation as described in the present paper. In addition, Raman Spectroscopy (RAMAN), X-ray Fluorescence (XRF), Gas Chromatography-Mass Spectrometry (GC-MS), also would add information regarding chemistry indicating more specific possible taphonomic processes that occurred after deposition [24].

\section{Conclusion}

This stratigraphic distribution of the sedimentary facies reflects differences in the depositional style of the paleo-coastal system through time, probably as a function of episodic transgressive-regressive cycles, in shallow marine to a transitional (lagoon, reef, estuarine) and continental environments.

As in Kullberg et al. [25], the western Iberian margin constitutes a passive margin during the late Berriasian-late Aptian, gradually creating full marine conditions southwards by the opening of the shelf to the Atlantic Ocean [26] with a rapid rise in relative sea-level $[6,27]$.

More specifically, it demonstrates an evolution from a lagoon-like (cat's- pond) environment, more closed, to a coastal marine environment. Between these two depositional phases, the increase in the sandy fraction indicates the opening of the lagoon and, possibly, an estuarine episode and agrees with description provided already [19].

\section{Acknowledgements}

The authors would like to thank Centro Português de Geo-História e Pré-História, Lisbon/Golegã, Portugal. Aditionally authors thank to Pedro Proença Cunha for his revision and the suggestions on the original text. Authors would also like to thank all the team members who have collaborated in the fieldwork; Ciência Viva-Agência Nacional para a Cultura Científica e Tecnológica, which has financially supported part of the fieldwork since 2002 through the program "Ocupação Científica dos Jovens nas Férias" (Scientific Occupation of Youngsters during Holidays), involving young people of the secondary school level.

\section{References}

[1] Figueiredo, S. 2002. "Os dinossauros da Arrábida." Evolução 1: 5-8.

[2] Figueiredo, S. 2004. "Os dinossauros do Cabo Espichel." Techne 9: 285-290.

[3] Sauvage, H. E. 1897. Vertébrés fossils du Portugal. Lisboa: Direction des Travaux Géologiques du Portugal.

[4] Lapparent, A. F. de, and Zbyszewski, G. 1957. "Les dinosauriens du Portugal." Memórias dos Serviços Geológicos de Portugal Lisboa (N.S.) 2: 1-63.

[5] Galton, P. M. 1994. "Notes on Dinosauria and Pterodactyla from the Cretaceous of Portugal." Neue Jhrbuchfür Geologieund Paläontologie 194: 253-267.

[6] Carvalho, C. N., Viegas, P., and Cachão, M. 2007. "Thalassinoides and Its Producer: Populations of Mecochirus Buried within Their Burrow Systems, Boca do Chapim Formation (Lower Creataceous), Portugal." Palaios 22: 107-112.

[7] Antunes, M. T., and Mateus, O. 2003. "Dinosaurs of Portugal." Comptes Rendus, Palevol 2: 77-95.

[8] Figueiredo, S. 2000. "Classificação do dente $\mathrm{n}^{\circ} 10$ do Museu Geológico.” Boletim do Centro Português de Geo-História e Pré-História I (1): 3.

[9] Taylor, M. P. 2010. "Sauropod Dinosaur Research: a Historical Review". Geological Society, London, Special Publications 343: 361-386.

[10] Buffetaut, E. 2007. “The Spinosaurid Dinosaur Baryonyx (Saurischia, Theropoda) in the Early Cretaceous of Portugal." Geological Magazine 144: 1021-1025.

[11] Antunes, M. T. 1976. "Dinossáurios Eocretácicos de Lagosteiros." Ciências da Terra 1: 1-35. 
[12] Antunes, M. T. 1990. "Dinossáurios em Sesimbra e Zambujal: episódios de há cerca de 140 milhões de anos." Sesimbra Cultural 0: 12-14.

[13] Dantas, P. 1990. "Dinossáurios de Portugal." Gaia 2: 17-26.

[14] Galopim de Carvalho, A. M. G., and Santos, V. 1992. "Sesimbra, um Pólo importante para o conhecimento da história dos dinossáurios em Portugal.” Sesimbra Cultural 2: 6-9.

[15] Galopim de Carvalho, A. M. G., and Santos, V. 1993. "Pegadas de Dinossáurios de Sesimbra." Sesimbra Cultural 3: 10-14.

[16] Mateus, O., Araújo, R., Natário, C., and Castanhinha, R. 2011. "A New Specimen of the Theropod Dinosaur Baryonyx from the Early Cretaceous of Portugal and Taxonomic Validity of Suchosaurus." Zootaxa 2827: 54-68.

[17] Figueiredo, S. 2010. "Breve Notícia sobre a Descoberta de um Novo Dinossáurio Ornitópode no Cabo Espichel." Boletim do Centro Português de Geo-História e Pré-História III 4: 7-15.

[18] Figueiredo, S. 2014. Os Dinossáurios em Território Português: as espécies, as jazidas e os fósseis. Lisboa: Chiado Editora.

[19] Figueiredo, S., Rosina, P., and Figuti, L. 2015. "Dinosaurs and Other Vertebrates from the Papo-Seco Formation (Lower Cretaceous) of Southern Portugal." Journal of Iberian Geology 41 (3): 301-314.
[20] Manupella, G., Antunes, M. T., Pais, J., Ramalho, M. M., and Rey, J. 1999. Notícia Explicativa da Carta Geológica de Setúbal. Lisboa: Serviços Geológicos de Portugal.

[21] Holz, M., and Simões, M. G. 2002. Elementos Fundamentais de Tafonomia. Porto Alegre: UFRGS.

[22] Behrensmeyer, A. K. 1982. "Time Resolution in Fluvial Vertebrate Assemblages." Paleobiology 8 (3): 211-227.

[23] Behrensmeyer, A. K. 1988. "Vertebrate Preservation in Fluvial Channels." Palaeogeography, Palaeoclimatology, Palaeoecology 63 (1): 183-199.

[24] Schweitzer, M. H., Avci, R., Collier, T., and Goodwin, M B. 2008. "Microscopic, Chemical and Molecular Methods for Examining Fossil Preservation." Comptes Rendus Palevol 7 (2-3): 159-184.

[25] Kullberg, J. C., da Rocha, R. B., Soares, A. F., Duarte, L. V., and Marques, J. F. 2014. "Palaeogeographical Evolutionof the Lusitanian Basin (Portugal) during the Jurassic. Part I: The Tectonic Constraints and Sedimentary Response.” In STRATI 2013 (pp. 665-672). Cham: Springer International Publishing.

[26] Rey, J. 1972. "Recherches géologiques sur le Crétacé inférieur de l'Estremadura (Portugal)." Memórias dos Serviços Geológicos de Portugal 21. 1-477.

[27] Dinis, J. L., Rey, J., Cunha, P. P., Callapez, P., and Dos Reis, R. P. 2008. "Stratigraphy and Allogenic Controls of the Western Portugal Cretaceous: an Updated Synthesis." Cretaceous Research 29 (5): 772-780. 